\title{
Erratum to: TLR1/2, TLR7, and TLR9 Signals Directly Activate Human Peripheral Blood Naive and Memory B Cell Subsets to Produce Cytokines, Chemokines, and Hematopoietic Growth Factors
}

\author{
Sudhanshu Agrawal • Sudhir Gupta
}

Published online: 12 October 2010

(C) Springer Science+Business Media, LLC 2010

\section{Erratum to: J Clin Immunol}

DOI 10.1007/s10875-010-9456-8

The original version of this article unfortunately contained a mistake.

Reference number 20 should be deleted and references should be renumbered thereafter ( 21 will change to 20,22 to 21 . .36 to 35$)$. 